\title{
A.J.TE
}

African Journal of Teacher Education

ISSN 1916-7822. A Journal of Spread Corporation

Volume 10. No. 12021 Pages 172-194

\section{The Paradox of Ghanaian High School Mathematics Teachers' Perspectives on ICT Use}

\author{
Farouq Sessah Mensah ${ }^{1}$ \& Douglas Darko Agyei ${ }^{2}$ \\ ${ }^{1}$ Ekumfi T.I. Ahmadiyya SHS, Department of Mathematics and ICT, Ekumfi Essarkyir, Ghana \\ ${ }^{2}$ University of Cape Coast, Department of Mathematics and ICT Education, Ghana
}

\begin{abstract}
The paper sought to investigate the perceived use of Information Communication Technology (ICT) of high school mathematics teachers in Ghana. A hundred high school mathematics teachers from 20 public schools, 10 each located in the rural and urban areas respectively in the Central region of Ghana, were stratified and used in the study. A questionnaire and semi-structured interviews were used to collect data. The result of the study indicated low levels of perceived knowledge/skills of ICT use by high school mathematics teachers, contrary to their reported high usage levels of ICTs. The findings of the study also indicated that the high school mathematics teachers' ICT use in a professional related context (instructional delivery, assessment, and professional learning network) was minimal compared to use for social networking, although they seemed to be fully aware of the relevance of using ICT in a professional related manner. Similarly, their reported technical knowledge/skills of ICT were low. Thus, the results of the study suggest that, though the teachers reported high ICT usage, actual usage seems to be at the peripheries. Among other things, this study has implications for curriculum development and training in Ghana and countries of similar context. It may be necessary for the Curriculum Research Development Division (CRDD) of the Ghana Education Service in collaboration with the related agencies to explicitly define parameters such as what ICT tools must be used, when they must be used, and how they should be used when reviewing and revising their mathematics teaching curriculum.
\end{abstract}

Keywords: Social Network, PLN, Assessment, Instructional Delivery, ICT

\section{INTRODUCTION}

The adoption of ICTs into the educational system has become a central issue for almost every nation in the world (Agyei \& Voogt, 2012). The significant role ICTs play in any educational system cannot be overemphasized. To prepare learners for the 21 st-century job market, educational institutions need to incorporate ICTs into their curriculum (Yelland, 2001). In this perspective, 
Ghana's 1997 World Links for Development (WorLD) programme was intended to use ICT to create an opportunity for teachers to learn. The objective of the programme was to assist teachers to integrate ICTs into their curricula (Kwei, 2001). Similarly, there has been an ICT for Accelerated Development (ICT4AD) policy that seeks to provide a framework in which ICT will be used to transform the educational sector, allowing all Ghanaians to pursue quality life-long learning opportunities regardless of their geographical location (Republic of Ghana, 2003).

The primary objective of teaching mathematics is to help the learner to gain the kind of understanding and abilities that will bring about desirable changes in him or her. This objective can be achieved if the educational system offers a conducive and enabling environment where learners can think objectively, critically, and analytically and consequently be an agent of change. Several studies have shown the relevance of ICTs in mathematics education (Agyei \& Voogt, 2012; Mensah, 2017).

Assessment is an essential component of the school system in which ICT plays a mammoth role by helping teachers to provide informed and precise feedback on the progress and achievement of the learner. Likewise, ICTs are being used in assessment and reporting within the school system (Mensah, 2017). Preparing examination data and providing informed feedback to stakeholders has become very simple with the use of ICT (Zhang, Clifton, \& Shen, 2007). Stakeholders can readily access the progress and achievement of a learner in the comfort of their homes. Furthermore, relevant literature has shown that the professional use of ICTs by teachers is often interwoven with their social use (Marriott, Marriott \& Selwyn, 2004; Selwyn, 2008, Mensah, 2017). This phenomenon turns the attention of teachers away from using ICTs in professional related contexts and studies have shown their adverse impact on learning outcomes (Junco, 2012; Rosen, Carrier, \& Cheever, 2013). In the Ghanaian context, little scholarly attention has been paid to how high school mathematics teachers use ICT for social purposes. This study contributes to filling this gap in the literature.

High school mathematics teachers join Professional Learning Networks (PLNs) to prepare them for the requirements of a mathematics educator. With PLN, high school mathematics teachers can tap into the knowledge of thousands of mathematics educators around the globe (Weisgerber \& Butler, 2011). The use of ICTs by high school mathematics teachers to improve their professional development is also an area of concern that is yet to be explored. What then could high school mathematics teachers be using ICTs for to the benefit of their professional 
development? This is what the current researchers sought to investigate. The study addressed the following research issues; what are high school mathematics teachers ' perceived knowledge/skills in ICTs?; what do high school mathematics teachers use ICT for?; and what is the relationship between high school mathematics teachers' perceived knowledge/skills in ICTs and their ICT use?

\section{CONCEPTUAL FRAMEWORK}

The conceptual framework describes the flow of the research and the relationship between the variables that have been investigated. The study design was based on the variables used in the objectives. To guide the study methodology and interpret the data from within the theoretical context, the conceptual framework as shown in Figure 1 was used.

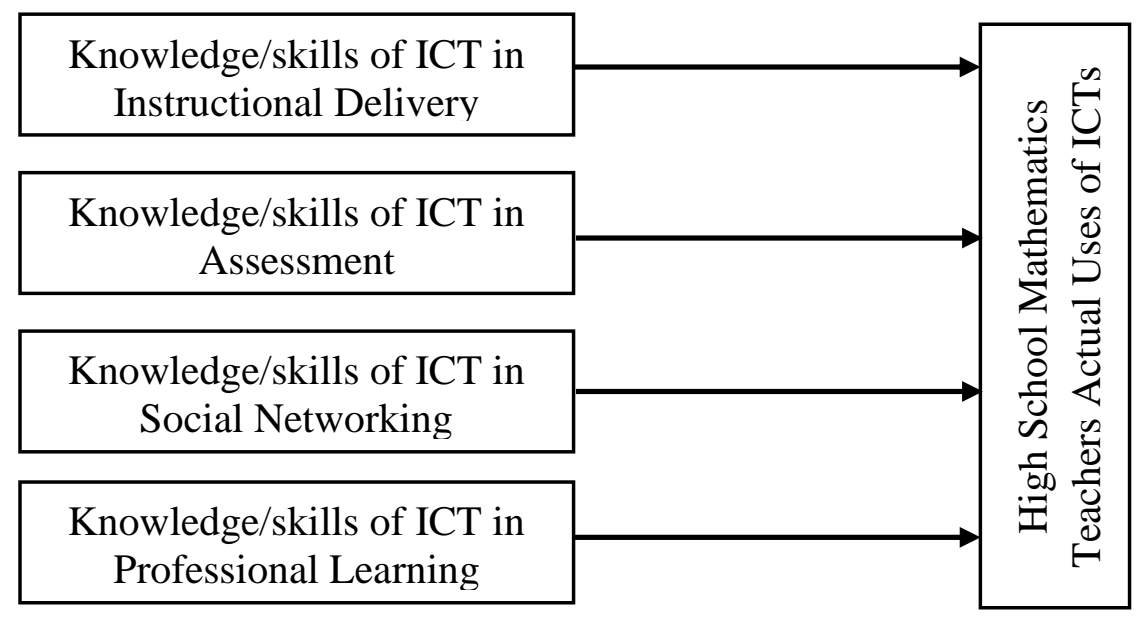

Figure 1: Conceptual framework of the study

The above conceptual framework demonstrates how high school mathematics teachers use ICTs. The framework shows how high school mathematics teachers' perceived ICT knowledge/skills in instructional delivery, assessment, social networking, and professional learning network influence their actual use of ICTs. The actual use of ICT is operationalized as the extent of agreement on using ICTs.

The accessibility of ICTs has altered the nature of mathematics teaching among Ghanaian mathematics high school teachers (Buabeng-Andoh, 2015). Extant literature (e.g., BuabengAndoh, 2015; Joshi, 2017; Mensah 2017) demonstrates that ICTs have a positive relationship with the teaching of mathematical skills. The findings vary depending on how ICTs are used.

ICTs also play significant roles in the assessment process. Some high school mathematics teachers can now use digital assessment systems (Leigh-Lancaster, 2010). ICTs enable teachers to AJOTE Vol. 10.1 (2021), 172-194 
process their examination data and to announce the outcomes as quickly as possible (LeighLancaster, 2010). The framework indicates that high school mathematics teachers use ICTs for assessment purposes. This is explored with the setting of the end-of-term examination or class test, marking of objective test, grading of students exams, and reporting of feedback to stakeholders.

Social networking is characterized by several technological instruments that emphasize social elements in the form of a communication funnel, collective learning, and creative articulation (Al-Rahmi \& Othman, 2013). It is not surprising to see teachers glued to their smartphones in classrooms, during commutes and at periods of relaxation (Walmsley, White, Eynon, \& Somerfield, 2003; Marriott, Marriott, \& Selwyn, 2004; Salih, 2004; Selwyn, 2008). In

this study, the researchers attempted to investigate what high school mathematics teachers make of social networking. Trust (2012) observes that PLNs being teacher-driven, support groups of individuals globally, reducing isolation while encouraging independence. PLNs provide immediate access to information and facilitates association with a vast number of individuals with different abilities.

\section{RESEARCH METHODOLOGY}

The study adopted a mixed-method research design, using an explanatory sequential approach (Creswell, 2013). The rationale for using an explanatory sequential strategy is based on the knowledge that quantitative data and their subsequent statistical analysis provide a particular knowledge of the study problem (Ivankova, Creswell, \& Plano Clark, 2007). The qualitative data and their analysis refine and clarify the statistical outcomes through a more in-depth exploration of the opinions of the respondents (Creswell, 2012).

The population of the study comprised of all public high school mathematics teachers from the 63 high schools in the Central region of Ghana. High school mathematics teachers in the central region were 693, made up of 431 males and 262 females (MOE, 2020). In the quantitative stage, a stratified sampling technique was employed to select 100 high school mathematics teachers. These teachers were drawn from 20 high schools in the Central Region of Ghana. Krejcie and Morgan's (1970) table for sample size determination from a specified population was used. This sample size is considered to be comparatively large, fairly sufficient, and representative of the population.

A stratified sampling technique was used in this study because the high schools in the 
Central region are located in both rural and urban districts. Therefore to be able to get equal representation of high schools from both rural and urban settings, a stratified sampling technique was employed. The population in each of the stratum was approximately about the same and hence the sampling fraction was the same for each stratum. The researchers divided the Central region into urban and rural districts. A simple random sampling technique was employed to select 10 high schools from the urban districts and 10 high schools from the rural districts. Five mathematics teachers were then conveniently selected from each selected school in the rural and urban districts making a total of 100 high school mathematics teachers.

At the qualitative stage, the maximal variation sampling technique was used. The maximal variation sampling technique is, according to Creswell and Garrett (2008), a purposeful sampling technique for choosing respondents in which the researcher samples cases or people that vary on certain characteristics. The researchers used maximal variation sampling technique in this study to select high school mathematics teachers based on these criteria: (1) the perceived knowledge/skills ICTs, (2) readiness to engage in the research, (3) the availability of ICT infrastructure, and (4) demographic features such as gender. Perceived knowledge/skills of ICTs were measured using a five-point Likert scale, readiness to engage in the study was accessed through the informed consent form, availability of ICT infrastructure was through visitation to the schools to observe and gender of the respondent by the respondents' physical outlook.

Following a thorough analysis of the appropriate literature, a self-administered questionnaire and semi-structured interview were used as the tools to gather information to answer the questions set for this research. The questionnaire was used as it requires less time to administer them and also guarantees that participants are anonymous (Fraenkel \& Wallen, 2000; Muijs, 2004). The researchers developed the survey questionnaire for the current study by adapting previously developed instruments, including those of Litchy (2000), Sahin and Thompson (2006), and Srisurichan (2012). To check for the validity of the instrument, the researchers allowed two senior colleagues in the field of educational technology and mathematics education to evaluate the questionnaire for content and construct as well as face validity. After the panel's feedback was received, the necessary changes to the content of the questionnaire were made. Later, the improved questionnaire was pilot-tested to establish not only its reliability but also to identify defective items and ensure that the instrument was clearly understood by respondents. The SHS mathematics teachers' survey questionnaire showed a Cronbach alpha of 0.95. A letter seeking permission to 
carry out the research was then given to the Headmasters/Headmistress of the participating high schools. With consent from the Headmasters/Headmistress, the Heads of the mathematics department of the participating schools were informed about the study with participants completing an informed consent form.

The survey instrument for teachers in this study had three parts: Section A, B, and C. Section A had one question which was a Likert-type scale that had 35 items and asked high school mathematics teachers their perceived Knowledge/skills in ICT use for instruction delivery, assessment, social networking, and professional learning network activities. Section B had five questions that addressed mostly the ICT use in instruction delivery, assessment, social networking and professional learning network activities, and other information. Section $\mathrm{C}$ focused on high school mathematics teachers' socio-demographic information such as gender, school type, age, and teaching experience. The Likert-type scale items were coded as "strongly disagree" $=1$, "disagree" $=2$, "Neutral" $=3$, "agree" $=4$, and "strongly agree" $=5$.

As a follow-up to the answers provided in the study's quantitative stage, the researchers performed semi-structured interviews. For a period not exceeding 60 minutes, the researchers audiotaped each of the selected mathematics teachers for the qualitative phase of the study using an interview etiquette based on the quantitative results (data on the knowledge/skills of the participants with respect to ICTs, their actual use of ICTs, and their experiences in ICTs). Moreover, the researchers evaluated how participants responded to some specific items on the questionnaire.

Descriptive statistics such as mean and standard deviation were calculated for participants' responses to perceived knowledge/skills of ICT use in instructional delivery, learning, assessment, social networking, and professional learning networks. On the actual use of ICT by high school mathematics teachers, the researchers sought to answer this research question using mean, standard deviations, t-test, and a one-way Analysis of Variance (ANOVA). A correlation was used to answer research question 3 which sought to look at the relationship between high school mathematics teachers' perceived knowledge/skills of ICT and their actual usage. 


\section{RESULTS}

\section{Demographic Information of Respondents}

Gender, age, teaching experience, and average ICT use time were included in the demographic data. Of the 100 high school mathematics teachers sampled, the majority were males representing $67.0 \%(n=67)$ while the females were in the minority representing $33.0 \%(n=33)$. The results of the study indicated that the majority of the high school teachers sampled were aged 40 years and below representing $88.0 \%(n=88)$ while those aged 40 years and above were in the minority representing $12.0 \%(n=12)$ of the sample. The results of the study indicated that the majority $(66.0 \%, n=66)$ of the high school, mathematics teachers had four years and more teaching experience. Teaching experience could impact high school mathematics teachers' adoption of ICTs in their profession. This was evident in the qualitative face of the study as high school mathematics teachers with over four years of teaching experience had a lot to share on ICTs. Besides, about two-thirds (67.0\%) of participants reported using ICT for different reasons for an average of three hours or more a week. Table 1 presents the demographic distribution of the respondents.

Table 1 - Demographic Information of High School Mathematics Teachers

\begin{tabular}{llcc}
\hline Variable & Category & Frequency & $\mathbf{\%}$ \\
\hline \multirow{3}{*}{ Gender } & Male & 67 & 67.0 \\
& Female & 33 & 33.0 \\
& Total & $\mathbf{1 0 0}$ & $\mathbf{1 0 0 . 0}$ \\
& & & \\
& $20-30$ years & 38 & 38.0 \\
31-40 years & 50 & 50.0 \\
Age & $41-50$ years & 11 & 11.0 \\
& $51-60$ years & 1 & 1.0 \\
& Total & $\mathbf{1 0 0}$ & $\mathbf{1 0 0 . 0}$ \\
& & & \\
Teaching Experience & Less than one year & 9 & 9.0 \\
& $1-3$ years & 25 & 25.0 \\
& $4-6$ years & 40 & 40.0 \\
& $7-10$ years & 16 & 16.0
\end{tabular}


11 years and above

Total

None

Less than 1 hour

1 hour or more, but less than 3 hours

3 hours or more, but less than 5 hours

5 hours or more, but less than 10

hours

10 hours or more

Total
10

100

10.0

100.0

28

25

23

19

19.0

100

\section{0}

\section{High School Mathematics Teachers' Perceived Knowledge/Skills of ICTs}

To answer research question 1, high school mathematics teachers' perceived knowledge/skills of ICTs were discussed. The perceived knowledge/skills of ICTs were classified into four; perceived knowledge/skills of ICTs for mathematics instructional delivery, mathematics assessment, social networking, and professional learning network in mathematics education. Any mean value from $0-2.5$ was classified as low perceived knowledge/skills and a mean value from $2.6-5.0$ was classified as high perceived knowledge/skills. As shown in Table 2, perceived knowledge/skills of ICT for social networking had the highest mean score (mean $=3.86, S D=0.97, C V=25.13 \%$ ) showing high perceived knowledge/skills of ICT for social networking. There were low perceived knowledge/skills of ICT tools for mathematics instructional delivery (mean $=2.55, S D=$ $0.82, C V=32.16 \%$ ), professional learning network in mathematics (mean $=2.39, S D=$ $1.08, C V=45.19 \%)$ and mathematics assessment (mean $=2.10, S D=0.74, C V=35.24 \%)$. Generally, overall perceived knowledge/skills of ICTs (mean $=2.73, S D=0.51, C V=$ 18.68\%) was low. Table 2 shows the descriptive statistics of respondents' perceived knowledge/skills of ICTs.

Table 2 - High School Mathematics Teachers' Perceived Knowledge/Skills of ICTs $(N=100)$

\begin{tabular}{lccc}
\hline Perceived Knowledge/Skills of ICTs & Mean & $\begin{array}{c}\text { Std. } \\
\text { Deviation }\end{array}$ & $\begin{array}{c}\text { Coefficient of } \\
\text { variation (\%) }\end{array}$ \\
\hline Mathematics Instructional Delivery & 2.55 & 0.82 & 32.16 \\
\hline
\end{tabular}

AJOTE Vol. 10.1 (2021), 172-194 


\begin{tabular}{|c|c|c|c|}
\hline Mathematics Assessment & 2.10 & 0.74 & 35.24 \\
\hline Social Networking & 3.86 & 0.97 & 25.13 \\
\hline Professional Learning Network in Mathematics & 2.39 & 1.08 & 45.19 \\
\hline Overall Knowledge of ICT Usage Type & 2.73 & 0.51 & 18.68 \\
\hline
\end{tabular}

Interview data gave researchers more insight into the low perceived knowledge/skills of ICT as reported in the quantitative phase of the study. When asked how well they use mathematical software for instructional delivery, the respondent stated low knowledge levels. One of the respondents reported;

"While I sometimes use it, I'm not very good at Excel. I am still in the process of learning"

The qualitative results indicated that mentorship is lacking. Apparently, this could explain the low perceived knowledge/skills of ICTs by high school mathematics teachers. A respondent reiterated;

"As professionals, we need a learning platform where we could share ideas on how to teach specific content. Apparently, these learning platforms are not available."

This seemed to imply that the technology implementation program (ICT4AD) in schools was not pulling through because high school mathematics teachers were not mentored.

One of the topics identified as a reason for the low perceived knowledge/skills of ICTs was inadequate training. Respondents stated that training sessions were very brief, often during school holidays or pre-service education. There was no time for teachers to reflect on the perceived knowledge/skills they had gained. Respondents felt they didn't have enough ICT knowledge/skills for school use and out-of-school use. However, finding out that some high school mathematics teachers used ICT for self-training was exciting. A respondent indicated;

“...I have enrolled in a free online learning programme... You can have access to all the resources you need from the internet to support your teaching. Just google it...”

\section{High School Mathematics Teachers' Actual Use of ICTs}

To answer research question 2, the actual use of ICTs by high school mathematics teachers was discussed. High school mathematics teachers reported high ICT use (mean $=4.23, S D=$ $0.68, C V=16.08 \%$ ) in general. However, the most ICT usage type reported by high school AJOTE Vol. 10.1 (2021), 172-194 
mathematics teachers was for social networking ( mean $=4.36, S D=0.75, C V=17.20 \%$ ). This was followed closely by ICT use for mathematics assessment purposes $($ mean $=4.21, S D=$ $0.89, C V=21.14 \%$ ), ICT use for mathematics instructional delivery (mean $=4.20, S D=$ $0.89, C V=21.19 \%)$ and lastly, ICT usage for professional learning network in mathematics ( mean $=4.13, S D=0.83, C V=20.10 \%$ ). This result was unexpected as high school mathematics teachers perceived knowledge/skills were low as reported in answering research question one. Table 3 demonstrates high school mathematics teachers' uses of ICT.

Table 3 - Mean scores of High School Mathematics Teachers' ICT Use $(N=100)$

\begin{tabular}{lccc}
\hline ICT Usage Type & Mean & $\begin{array}{c}\text { Std. } \\
\text { Deviation }\end{array}$ & $\begin{array}{c}\text { Coefficient of variation } \\
(\%)\end{array}$ \\
\hline Mathematics Instructional Delivery & 4.20 & 0.89 & 21.19 \\
Mathematics Assessment & 4.21 & 0.89 & 21.14 \\
Social Networking & 4.36 & 0.75 & 17.20 \\
Professional Learning Network in & 4.13 & 0.83 & 20.10 \\
Mathematics & & & 16.08 \\
Overall ICT Usage Type & 4.23 & 0.68 & \\
\hline
\end{tabular}

Contrary to the low perceived knowledge/skills of ICTs, the results of the study demonstrate high mean values of the actual use of ICTs. This result was, however, not expected since respondents would be expected to use only what they reported as their perceived knowledge/skills of ICTs (see Table 2). This seems to suggest that the high school mathematics teachers may have overestimated their perceptions of their actual use of ICT. This deduction is warranted from the information gathered from the interview. For example, one of the respondents mentioned;

"I only use Excel to record students' assessment scores and word in typing examination questions. However, I am unable to use Microsoft Word to draw mathematical diagrams..."

Another respondent also indicated;

“...I use my phone for text messages, calls, and WhatsApp... My colleagues tell me I could use my phone to send and receive emails, browse the internet, and more... ' 
From these results, it appears that high school mathematics teachers' knowledge/skills in ICTs were restricted to the generic use of applications and not for mathematics-specific instruction. Thus, the respondents use ICTs, but only at the peripheries, which might have affected their high mean scores in the quantitative data when they did not effectively maximize the potential of these ICTs in their profession.

While the information from the interview stated a comparable trend in ICT use, it provided a better image of the actual use of ICTs. It disclosed that most high school mathematics teachers use ICTs primarily for social networking (for WhatsApp communication, email, and Facebook) in line with the quantitative data (see Table 3). Some high school mathematics teachers also used ICTs for assessment (grading learners, sending feedback to parents, and typing questions for mathematics tests) and professional learning networks (collaborating with other mathematics educators from other schools). Respondents reiterated the potential of ICTs when used in professional-related contexts to improve learning outcomes. A respondent indicated;

"Using ICT in teaching mathematics makes students grasp the concept being taught easily... However, I must say it takes a lot of time to prepare an ICT embedded lesson..."

Despite the enormous potential of ICTs, the research interview data disclosed that high school mathematics classrooms did not fully adopt ICT as a medium for assisting in instructional delivery. A respondent stated

"We are not ready as teachers to change our mode of instructional delivery to include ICT. That is our problem..."

The research findings indicated that high school mathematics teachers did not use ICT in ways associated with instructional delivery and assessment in mathematics at their schools. High school mathematics teachers, however, used ICT for social networking and joining professional learning networks or, did not use ICT at all despite its accessibility.

A t-test was employed to find out if there exists any difference in high school mathematics teachers' use of ICTs concerning gender and school location. The results of the study indicated that there was no statistically significant difference between high school mathematics teachers' use of ICTs and their gender. Likewise, no statistically significant difference existed between high school mathematics teachers' use of ICTs and the location of their school. The results are presented in Table 4. 
Table 4 - T-Test of High School Mathematics Teachers' use of ICTs in Terms of Gender and School Location

\begin{tabular}{|c|c|c|c|c|c|c|c|}
\hline ICT Usage & Categories & $\mathbf{N}$ & Mean & $\begin{array}{l}\text { Std. } \\
\text { Deviation }\end{array}$ & df & $\mathbf{t}$ & Sig. \\
\hline Mathematics Instructional & Male & 67 & 4.19 & .913 & 67.10 & -0.27 & 0.792 \\
\hline Delivery & Female & 33 & 4.24 & .863 & & & \\
\hline \multirow[t]{2}{*}{ Mathematics Assessment } & Male & 67 & 4.23 & .936 & 72.16 & 0.30 & 0.769 \\
\hline & Female & 33 & 4.17 & .817 & & & \\
\hline \multirow[t]{2}{*}{ Social Networking } & Male & 67 & 4.32 & .774 & 70.68 & -0.77 & 0.445 \\
\hline & Female & 33 & 4.44 & .691 & & & \\
\hline \multirow{2}{*}{$\begin{array}{l}\text { Professional Learning } \\
\text { Network in Mathematics }\end{array}$} & Male & 67 & 4.08 & .897 & 81.02 & -0.91 & 0.364 \\
\hline & Female & 33 & 4.23 & .683 & & & \\
\hline \multirow{3}{*}{$\begin{array}{l}\text { Mathematics Instructional } \\
\text { Delivery }\end{array}$} & Rural & 50 & 4.29 & 0.87 & 97.78 & 0.98 & 0.331 \\
\hline & & & & & & & \\
\hline & Urban & 50 & 4.12 & 0.91 & & & \\
\hline \multirow[t]{2}{*}{ Mathematics Assessment } & Rural & 50 & 4.32 & 0.80 & 94.45 & 1.23 & 0.221 \\
\hline & Urban & 50 & 4.10 & 0.98 & & & \\
\hline \multirow[t]{2}{*}{ Social Networking } & Rural & 50 & 4.31 & 0.77 & 97.62 & -0.68 & 0.496 \\
\hline & Urban & 50 & 4.41 & 0.73 & & & \\
\hline \multirow{2}{*}{$\begin{array}{l}\text { Professional Learning } \\
\text { Network in Mathematics }\end{array}$} & Rural & 50 & 4.27 & 0.79 & 97.20 & 1.67 & 0.098 \\
\hline & Urban & 50 & 4.00 & 0.86 & & & \\
\hline
\end{tabular}

$*$ Significant $(\mathrm{p}<0.05) ; * *$ Highly Significant $(\mathrm{p}<0.001)$

A one-way ANOVA was employed to determine if high school mathematics teachers' use of ICTs differs in terms of age and teaching experience. The results of the study indicated a statistically significant difference between high school mathematics use of ICTs for social AJOTE Vol. 10.1 (2021), 172-194 
networking and their age $(t=5.328, d f=99, p=0.002)$. The younger high school mathematics teachers used ICTs for social networking more than the older high school mathematics teachers. Similarly, the results of the study indicated a statistically significant difference between the use of ICTs for assessment purposes and the teaching experience of high school mathematics teachers $(t=3.048, d f=99 p=0.021)$. The younger high school mathematics teachers used ICTs for assessment more than the older high school mathematics teachers. However, the other uses of ICTs showed no statistically significant difference with respect to age and teaching experience of high school mathematics teachers. 
Table 5 - ANOVA of High School Mathematics Teachers' use of ICTs in Terms of Age and

\begin{tabular}{|c|c|c|c|c|c|c|}
\hline \multicolumn{2}{|l|}{ ICT Usage Type } & \multirow{2}{*}{\begin{tabular}{|l|} 
Sum of Squares \\
4.269 \\
\end{tabular}} & \multirow{2}{*}{\begin{tabular}{|l|}
$\mathbf{d f}$ \\
3 \\
\end{tabular}} & \multirow{2}{*}{$\begin{array}{l}\begin{array}{l}\text { Mean } \\
\text { Square }\end{array} \\
1.423 \\
\end{array}$} & \multirow{2}{*}{$\begin{array}{l}\mathbf{F} \\
1.830\end{array}$} & \multirow{2}{*}{$\begin{array}{l}\text { Sig. } \\
0.147\end{array}$} \\
\hline Mathematics Instructional Delivery & Between Groups & & & & & \\
\hline & Within Groups & 74.659 & 96 & 0.778 & & \\
\hline & Total & 78.928 & 99 & & & \\
\hline \multirow[t]{3}{*}{ Mathematics Assessment } & Between Groups & 1.061 & 3 & 0.354 & 0.434 & 0.729 \\
\hline & Within Groups & 78.140 & 96 & 0.814 & & \\
\hline & Total & 79.201 & 99 & & & \\
\hline \multirow[t]{3}{*}{ Social Networking } & Between Groups & 7.875 & 3 & 2.625 & 5.328 & $0.002 *$ \\
\hline & Within Groups & 47.301 & 96 & 0.493 & & \\
\hline & Total & 55.176 & 99 & & & \\
\hline \multirow{4}{*}{$\begin{array}{l}\text { Professional Learning Network in } \\
\text { Mathematics }\end{array}$} & Between Groups & 3.681 & 3 & 1.227 & 1.817 & 0.149 \\
\hline & Within Groups & 64.813 & 96 & 0.675 & & \\
\hline & Total & 68.494 & 99 & & & \\
\hline & Between Groups & 2.819 & 4 & 0.705 & 0.880 & 0.479 \\
\hline \multirow{2}{*}{$\begin{array}{l}\text { Actual use of ICT for Mathematics } \\
\text { Instructional Delivery }\end{array}$} & Within Groups & 76.109 & 95 & 0.801 & & \\
\hline & Total & 78.928 & 99 & & & \\
\hline \multirow{3}{*}{$\begin{array}{l}\text { Actual use of ICT for Mathematics } \\
\text { Assessment }\end{array}$} & Between Groups & 9.012 & 4 & 2.253 & 3.049 & $0.021 *$ \\
\hline & Within Groups & 70.189 & 95 & 0.739 & & \\
\hline & Total & 79.201 & 99 & & & \\
\hline \multirow{3}{*}{$\begin{array}{l}\text { Actual use of ICT for Social } \\
\text { Networking }\end{array}$} & Between Groups & 2.799 & 4 & 0.700 & 1.269 & 0.288 \\
\hline & Within Groups & 52.376 & 95 & 0.551 & & \\
\hline & Total & 55.176 & 99 & & & \\
\hline \multirow{3}{*}{$\begin{array}{l}\text { Actual use of ICT for Professional } \\
\text { Learning Network in Mathematics }\end{array}$} & Between Groups & 3.134 & 4 & 0.784 & 1.139 & 0.343 \\
\hline & Within Groups & 65.360 & 95 & 0.688 & & \\
\hline & Total & 68.494 & 99 & & & \\
\hline
\end{tabular}

Teaching Experience

*Significant $(p<0.05) ; *$ Highly Significant $(p<0.001)$ 


\section{Relationship between High School Mathematics Teachers' Perceived Knowledge/Skills of ICTs and Their Use of ICTs}

To answer research question three, the relationship between the perceived knowledge/skills of ICTs and the actual use of ICTs by high school mathematics teachers was discussed. The results of the study indicated that the correlation between the perceived knowledge/skills of ICTs in instructional delivery and the actual use of ICTs for instructional delivery was positive and statistically significant $(r=0.27, p<0.01)$, as shown in Table 6. Similarly, the results of the study also found a positive and statistically significant relationship between the perceived knowledge/skills of ICTs in assessment and the actual use of ICTs for assessment $(r=0.22, p<$ 0.05). Furthermore, the results of the study showed that the correlation between the perceived knowledge/skills of ICTs for social networking and the actual use of ICTs for social networking was positive but not statistically significant $(r=-0.09, p>0.01)$. Finally, the results of the study indicated that the correlation between the perceived knowledge/skills of ICTs for professional learning networks and the actual use of ICTs for professional learning networks were positive and not statistically significant $(r=0.13, p>0.01)$. The results of the correlation between high school mathematics teachers' perceived knowledge/skills of ICTs and their actual use of ICTs are presented in Table 6. 


\section{Table 6 - Correlation Matrix of High School Mathematics Teachers' ICTs and their Perceived Knowledge/Skills of ICTs}

\begin{tabular}{|c|c|c|c|c|c|}
\hline \multirow{3}{*}{ 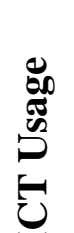 } & & \multicolumn{4}{|c|}{ ICT Usage } \\
\hline & & Mathematics & Mathematics & Social & Professional Learning \\
\hline & & Instructional Delivery & Assessment & Networking & Network in Mathematics \\
\hline$\ddot{0}$ & Mathematics Instructional Delivery & $0.27^{* *}(0.00)$ & & & \\
\hline$\frac{7}{\sqrt{2}}$ & Mathematics Assessment & & $0.22^{*}(0.02)$ & & \\
\hline 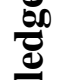 & Social Networking & & & $-0.09(0.09)$ & \\
\hline$\stackrel{8}{0}$ & Professional Learning Network in Mathematics & & & & $0.13(0.11)$ \\
\hline
\end{tabular}

**. Correlation is significant at the 0.01 level (2-tailed).

*. Correlation is significant at the 0.05 level (2-tailed). 


\section{DISCUSSION}

The study results were discussed in line with the research questions which were the perceived knowledge/skills of ICTs, the actual use of ICTs, on the one hand, and the relationship between the perceived knowledge/skills of ICTs and the actual use of ICTs by high school mathematics teachers, on the other. In line with research question 1, the study investigated the perceived knowledge/skills of ICTs by high school mathematics teachers. The results showed that the perceived knowledge/skills of ICTs by high school mathematics teachers was low. The results of the study are consistent with Agyei \& Voogt (2012) and Amuko, Miheso \& Ndethiu (2015) who found in their studies that Ghanaian and Kenyan teachers respectively have low knowledge/skills of ICTs. Evidence from the interview data also suggests that high school mathematics teachers have low perceived knowledge/skills of ICTs.

In a research undertaken by Mueller, Wood, Willoughby, Ross, and Specht (2008), their results indicated that training and continued support of excellent practice were among the most important determinants of effective development of ICT knowledge/skills. The qualitative data revealed in this research that high school mathematics teachers lacked appropriate training and mentorship to fully develop ICT knowledge/skills. The study results agree that ICT training would be required to allow high school mathematics teachers to fully obtain ICT knowledge/skills for mathematics instructional delivery, mathematics assessment, social networking, and professional learning network in mathematics. These results mirror those of Forgasz (2002) who discovered that mathematics teachers in Australia want to engage in ICT training to acquire mathematicsrelated application software knowledge/skills. According to Kamau (2014), ICT training can help teachers in mathematics to gain knowledge/skills and trust for ICT implementation in and outside their schools.

Research question 2 discussed the actual use of ICTs by high school mathematics teachers. The results of the study showed that high school mathematics teachers use ICT more for social networking operations than for mathematics instructional delivery, mathematics assessment, and mathematics PLN. The research outcome is consistent with Ogedebe, Emmanuel, and Musa (2012), who discovered social networking as a source of diversion from teaching and that Nigerian teachers used it more for social than professional purposes. Similarly, Peeraer and Van Petegem (2011) discovered that access to ICTs was not an obstacle to ICT integration but that private possession of ICTs by teachers in Belgium meant that computer usage was for purposes other than 
instructional delivery. The research finding also coincides with Mwalongo's (2015) findings in Tanzania that ICTs are used to prepare school announcements, records, examination and examination results, the scheme of work, letters, and student registration. The results of the study show that high school mathematics teachers have low knowledge/skills of ICTs in respect of mathematics instructional delivery, mathematics assessment, and PLN in mathematics. This may explain why high school mathematics teachers are using ICT more for social networking than for professional purposes.

In this study, an interesting observation that could be viewed as a contradiction was made. As stated in their studies on ICT by Anderson (2006), Bove'e, Voogt and Meelissen (2007), Tezci, (2009), the higher the average level of knowledge/skills of ICTs, the higher the use of ICTs. The present study does not match these prior ICT knowledge/skills studies and their actual use. The research showed low perceived knowledge/skills of ICTs but high use of ICTs. Several reasons might account for these interesting results of the study. One of these reasons might be that high school mathematics teachers do not have the technical knowledge/skills of ICTs, but are prepared to use them at the peripheries and therefore have high use recorded. Another reason might be that respondent overestimated their actual use of ICTs which is usual of survey self-reported data (Agyei \& Voogt, 2012).

Finally, several relationships were found in the last research question that sought to explore the relationship between the perceived knowledge/skills of ICTs of high school mathematics teachers and their actual use of ICTs. The results of the study showed a positive correlation between the perceived knowledge/skills of ICTs in instructional delivery and the use of ICTs for instructional delivery $(r=0.27, p<0.01)$. The research also found a positive and statistically significant relationship between the perceived knowledge/skills of ICTs in mathematics assessment and the use of ICT for mathematics assessment $(r=0.22, p<0.05)$. These findings are consistent with Sorgo, Verckovnik, and Kocijancic (2010) who discovered a positive correlation among Slovenia's science teachers' frequency of use of ICTs, perceived value, and teachers' ability to use ICTs. Sorgo, Verckovnik, and Kocijancic (2010) found in their study that the skills and confidence of teachers were predictors of the use of ICTs in teaching. 


\section{Practical Implications}

The present study can infer several practical implications. The study revealed that high school mathematics teachers generally have low knowledge/skill levels in ICTs. There is a need to create ICT training and resource hubs in the various districts by the state and other educational stakeholders. This will allow high school mathematics teachers to receive training on new ways of using ICT to enhance pedagogy, curriculum, and professional learning as well as to enhance their ICT knowledge/skills. Also, all institutions that train mathematics teachers should have a standardized training program on the inclusion of ICTs in mathematics instructional delivery. Instead of using the expertise obtained for non-professional contexts, the teacher education programs should be able to prepare teacher trainees to be able to fully incorporate ICTs into their careers.

\section{Limitations and Further Research}

The study was not without limitations. The questionnaire used self-reporting scales to measure variables for analysis. This may have influenced the research outcome as some of the participants may have overestimated their reactions. Moreover, the research includes only one region; the Central Region of Ghana. The literature review, however, contextualizes the research and helps to base the results and conclusions in the literature. More so, the use of ICTs in mathematics education is at a particularly vibrant point in Ghana, meaning fresh trends and announcements occur somewhere in the region on regular basis. The study must therefore be viewed as a blueprint of what was current at the time of study which due to rapid development facts and figures presented in this study may become outdated very quickly. The inconsistent finding from the present research indicates that an inverse relationship exists between knowledge/skills of ICTs and the use of ICTs for different reasons. This inverse relationship should be further explored.

\section{CONCLUSION}

Possession of the required knowledge/skills of ICTs is a significant factor that determines the extent and precise use of ICTs. Although a good number of high school mathematics teachers in the sampled schools rated themselves low on the perceived knowledge/skills of ICTs, they reported high use of ICTs. This is an interesting observation that could be viewed as a contradiction in the research. The results seem to establish that the high school mathematics teachers did not have the technical knowledge/skills of ICTs, but were frequently using ICTs at the peripheries and therefore 
reported high use of ICTs which is usual of self-report data. The study suggests an alarming and worrying state as mathematics teachers use ICT more for social networking instead of professional purposes (mathematics instructional delivery, mathematics assessment, PLN in mathematics). Yet high school mathematics teachers appeared to be fully aware of the advantages they could gain from using ICTs in their profession. This digital disconnection can be ascribed to endogenous and exogenous variables that this study did not pay attention to.

\section{REFERENCES}

Agyei, D. D., \& Voogt, J. (2012). Developing technological pedagogical content knowledge in pre-service mathematics teachers through collaborative design. Australasian Journal of educational technology, 28(4).

Al-Rahmi, W., \& Othman, M. (2013). The impact of social media uses on academic performance among university students: A pilot study. Journal of information systems research and innovation, 4(12), 1-10.

Amuko, S., Miheso, M., \& Ndethiu, S. (2015). Opportunities and Challenges: Integration of ICT in Teaching and Learning Mathematics in Secondary Schools, Nairobi, Kenya. Journal of Education and Practice, 24(6), 1-6

Andersson, S. B. (2006). Newly qualified teachers' learning related to their use of information and communication technology: A Swedish perspective. British Journal of Educational Technology, 37(5), $665-682$

Becta (2003). What the research says about using ICT in maths. UK: Becta ICT Research. Retrieved November 13, 2016, from http://www.becta.org.uk

Bovée, C., Voogt, J., \& Meelissen, M. (2007). Computer attitudes of primary and secondary students in South Africa. Computers in Human Behavior, 23(4), 1762 - 1776

Buabeng-Andoh, C., \& Issifu, Y. (2015). Implementation of ICT in learning: A study of students in Ghanaian secondary schools. Procedia-social and behavioral sciences, 191, 1282-1287.

Creswell, J. W. (2013). Research design: Qualitative, quantitative, and mixed methods approaches. USA: Sage publications.

Creswell, J. W., \& Garrett, A. L. (2008). The" movement" of mixed methods research and the role 
of educators. South African Journal of Education, 28(3), 321-333

Creswell, J., W. (2012). Educational Research: Planning, Conducting and Evaluating Quantitative and Qualitative Research, (4th edn). Boston: Pearson Education, Inc

Forgasz, H. (2002). Computers for learning mathematics: Gendered beliefs. In Annual Conference of the International Group for the Psychology of Mathematics Education 2002 (pp. 368375). The University of East Anglia.

Fraenkel, J. R., \& Wallen, N. E. (2003). How to design and evaluate research in education. McGraw-Hill Higher Education

Ivankova, N. V., Creswell, J. W., \& Plano Clark, V. L. (2007). Foundations and approaches to mixed methods research. First steps in research. Pretoria: Van Schaik, 253-282.

Joshi, D. R. (2017). Influence of ICT in mathematics teaching. International Journal For Innovative Research in Multidisciplinary Field, 3(1), 7-11.

Junco, R. (2012). In-class multitasking and academic performance. Computers in Human Behavior, 28(6), 2236-2243.

Kamau, L. M. (2014). Applying Rogers' Diffusion of innovations theory to investigate technology training for secondary mathematics teachers in Kenya. Journal of education and practice, 5(17), 19-31.

Krejcie, R. V., \& Morgan, D. W. (1970). Determining sample size for research activities. Educational and psychological measurement, 30(3), 607-610

Kwei, C. B. L. (2001). WorLD Ghana: Computer conflict, world ICT access. Retrieved on March 24, 2016 from www.iconnectonline.org/Stories/ Story.import109

Leigh-Lancaster, D. (2010). The case of technology in senior secondary mathematics: Curriculum and assessment congruence? A paper presented at the Australian Council for Educational Research Conference. Australia retrieved from http://research.acer.edu.au/ research_conference/RC2010/http://research.acer.edu.au/cgi/viewcontent.cgi?article=107 $4 \&$ context=research_conference

Marriott, N., Marriott, P., \& Selwyn, N. (2004). Accounting undergraduates' changing use of ICT and their views on using the Internet in higher education-a research note. Accounting 
Education, 13(sup1), 117-130.

Mensah, F. S. (2017). Ghanaian Tertiary Students' use of ICT. Global Journal of Human-Social Science Research, 1(9).

Ministry of Education (2020). Data on Senior High School Mathematics Teachers in Central Region of Ghana. Central Region Educational Directorate

Mueller, J., Wood, E., Willoughby, T., Ross, C., \& Specht, J. (2008). Identifying discriminating variables between teachers who fully integrate computers and teachers with limited integration. Computers \& Education, 51(4), 1523-1537.

Muijs, D. (2010). Doing quantitative research in education with SPSS. USA: Sage.

Mwalongo, A. I. (2014). Student Teacher and Lecturer Perceptions of the Use of Asynchronous Discussion Forums, Quizzes, and Uploaded Resources for Promoting Critical Thinking (Doctoral dissertation, University of Waikato).

Ogedebe, P. M., Emmanuel, J. A., \& Musa, Y. (2012). A survey on Facebook and academic performance in Nigeria Universities. International Journal of engineering research and applications, 2(4), 788-797.

Peeraer, J., \& Van Petegem, P. (2011). ICT in teacher education in an emerging developing country: Vietnam's baseline situation at the start of 'The Year of ICT'. Computers \& Education, 56(4), 974-982.

Rosen, L. D., Carrier, L. M., \& Cheever, N. A. (2013). Facebook and texting made me do it: Mediainduced task-switching while studying. Computers in Human Behavior, 29(3), 948-958.

Sahin, I., \& Thompson, A. (2006). Using Rogers' theory to interpret instructional computer use by COE faculty. Journal of Research on Technology in Education, 39(1), 81-104

Salih, U. S. U. N. (2004). Factors affecting the application of information and communication technologies (ICT) in distance education. Turkish Online Journal of Distance Education, 5(1).

Selwyn, N. (2008). Realising the potential of new technology? Assessing the legacy of New Labour's ICT agenda 1997-2007. Oxford Review of Education, 34(6), 701-712. 
Šorgo, A., Verčkovnik, T., \& Kocijančič, S. (2010). Information and communication technologies (ICT) in biology teaching in Slovenian secondary schools. Eurasia Journal of Mathematics, Science \& Technology Education, 6(1), 37-46.

Srisurichan, R. (2012). Teachers' accounts of successful technology integration in teaching mathematics. (Doctoral Dissertation, University of Wisconsin-Madison). Retrieved from https://www.learntechlib. org/p/121076/

Tezci, E. (2009). Teachers' effect on ICT use in education: The Turkey sample. Procedia-Social and Behavioral Sciences, 1(1), 1285-1294.

Trust, T. (2012). Professional learning networks designed for teacher learning. Journal of Digital Learning in Teacher Education, 28(4), 133-138.

Walmsley, A. D., White, D. A., Eynon, R., \& Somerfield, L. (2003). The use of the Internet within a dental school. European journal of dental education, 7(1), 27-33.

Weisgerber, C., \& Butler, S. H. (2011). Social media as a professional development tool: Using blogs, microblogs, and social bookmarks to create personal learning networks. Higher Education, 3, 339-363.

Yelland, N. (2001). Teaching and learning with information and communication technologies (ICT) for numeracy in early childhood and primary years of schooling. Canberra, ACT: Department of Education, Training, and Youth Affairs.

Zhang, F., Clifton, K. J., \& Shen, Q. (2007). Reexamining ICT impact on travel using the 2001 NHTS data for the Baltimore Metropolitan Area. In Societies and cities in the age of instant access (pp. 153-166). Springer, Dordrecht. 